\title{
ИСТОРИЈСКА ПОЗАДИНА УСМЕНОГ ЕПСКОГ НАРАТИВА О ЗИДАЊУ СКАДРА НА БОЈАНИ
}

Литература свједочи да је, не једном, изражено чуђење у вези са повезивањем Мрњавчевића и Скадра на Бојани у десетерачкој усменој епици. Одбацујући сугестију Николе Банашевића да изгледа да се браћа Мрњавчевићи не могу довести у везу са Скадром, односно са облашћу Скаgра уойшӣe, овај рад одгонета исходишта литерарних веза између Мрњавчевића и епског зидања града Скадра. Показује се да су Мрњавчевићи као сродници и сарадници зетских кнежева Балшића, затим позиција краља Вукашина у историји Зете и однос усмене књижевности према Балшићима вантекстовна подлога за улазак Мрњавчевића у усмени епски наратив о Скадру на Бојани. Чињенице о утицају Мрњавчевића на историјску стварност Зете сагледавамо у контексту природе историчности у епској усменој поезији: усмени епски наратив о Скадру на макроплану полази од стварности, а на микроплану трансформише историјске чињенице.

Кључне ријечи: Мрњавчевићи, Балшићи, Скадар на Бојани, усмена епика, историја

\section{Природа историчности}

Однос поезије према историји у десетерачким усменим пјесмама о зидању Скадра на први поглед дјелује збуњујуће. Ново Вуковић каже: „Скадар није Вукашинова престоница, нити је припадао његовим територијама, тако да остаје загонетно што неке народне пјесме везују Мрњавчевиће за овај град“ (Вуковић, 2001: 259). А Никола Банашевић сматра да „нема никакве основе да се браћа Мрњавчевићи доведу ма у какву везу не само са зидањем Скадра, градом много старијим, него ни са облашћу Скадра уопште“ (Банашевић, 1928: 374). Међутим, природа усмене епике и историја Зете воде другачијем разумијевању повезивања Мрњавчевића и Скадра у десетерачким усменим пјесмама.

* rosanda.bajovic@gmail.com 
Тумачећи легенду о зидању Скадра, Светислав Стефановић каже да „ако је, сад, легенда о зидању Скадра, морала постојати пре него што је везана за Мрњавчевиће, на Косову за Југовиће, у Босни за везира Соколовића, онда се она мора још раније датирати, вероватно што ближе или баш непосредно у вези са добом кад је Скадар у нашој народној историји играо врло важну улогу, прве државне и културне престонице под Бодином и његовим наследницима у X веку и доцније“ (Стефановић, 1933: 295). ${ }^{1}$ Стефановићево смјештање усмених пјесама о Мрњавчевићима у тринаести и четрнаести вијек Банашевић оспорава тиме што је краљ Вукашин погинуо 1371. године, што би требало да значи да је до повезивања зидања Скадра и Мрњавчевића у епској поезији дошло касније (Банашевић, 1928: 374). Овај Банашевићев закључак је логичан, али није прихватљива његова тврдња да се то десило „када су усмени певачи из тенденциозности или неинформисаности прекрајали историју“ (1928: 374).

Епски Скадар на Бојани „у народном поимању стоји тако да пјесника-пјевача нико није могао контролисати да ли је његова прича о постанку Скадра анахронизам или историјска реалија“ (Килибарда, 1982: 17). За разумијевање историчности у усменој пјесми није важна мјера подударања књижевних и историјских факата него то шта артефакт значи. Јован Деретић појашњава: „Ако се послужимо дистинкцијом између микро и макроисторије, односно 'историје кратког трајања' и 'историје дугог трајања', коју је увео француски историчар Бродел /Фернан Бродел, Списи о историји, Београд 1992, 87 _109/, онда бисмо могли рећи да се у једној песми много јасније рефлектују датости које спадају у сферу макроисторије него једнократни, појединачни догађаји који чине главно ткиво 'историје кратког трајања ““ (Деретић 1995: 205-206). Мирјана Детелић запажа да неисторијске

1 Стефановић за подршку свом закључку да је мотив узиђивања дјеце у грађевину старији од мотива узиђивања жене, противећи се Михаилу Арнаудову указује на древност мотива узиђивања дјеце у старозавјетној легенди о граду Јерихону - поменувши да је на исту паралелу указао Веселин Чајкановић (1933: 253). Он преноси и сажетак повијести о краљу Вортигерну (Vortigern) из Ненијусове (Nenius) „Историје Брита“ („Historia Britonum“), за коју се сматра да је написана почетком деветог вијека а у којој поменути краљ, након узалудних покушаја да на планини Сноудону (Snowdon) подигне град, на предлог друида узиђује дијете без оца (1933: 255). 
пјесме говоре о Мрњавчевићима као градитељима Скадра, али да су пјесме нових времена много ближе „званичној историографији, односно да није остао неопјеван ниједан важнији догађај повезан са скадарским везирима (Detelić, 2007: 388). У условима усмености, удаљавању од историјских факата по природи ствари подложнији су књижевни наративи о догађајима старих времена. Андрићев роман На Дрини ћуйрија (Андрић, 1985), у коме је из усмене књижевности преузет и прерађен и мотив жртвовања људског бића духу-покровитељу грађевине, у том смислу слиједи логику усмене епике.

Драгутин Костић закључује да је на краља Вукашина прешло епско пјевање о Јовану Кантакузину, па каже да је помјерању граница у пјевању о војводи Момчилу према Зети и Херцеговини допринијела и близина Скадра у који је песничка традиција смјестила краља Вукашина; односно, да је фонолошком сличношћу топонима превден у Пирлитор поред Дурмитора град Перитеорион (Peritheórion) - код кога се, године 1345, одиграла битка војника војводе Момчила и турских и ромејских војника (Костић, 1935: 454 455). ${ }^{2}$ А Деретић сматра да је колизија између престоног града Скадра и Пирлитора као средишта локалног господара војводе Момчила у пјесми „Женидба краља Вукашина“" (Вук, II, 25):

по свој прилици, много старија и од војводе Момчила и од краља Вукашина. У том случају Момчило би био на-

2 Потребно је указати и на један примјер криве рецепције односа поезије и историје у епској пјесми „Женидба краља Вукашина“ (Вук, II, 25). Витомир Вито Николић саопштава: „Дакле, херцега Стјепана је било и много прије Косача, па је по једном од њих, а не по Косачи, Херцеговина добила своје име. У то ће нас најбоље увјерити народна пјесма 'Женидба краља Вукашина', у којој се помиње Херцеговина читавих стотину година прије него је устоличен херцег Стјепан Косача“ (Николић, 2000: 142). Усмена поезија говори и о Мрњавчевићима као о онима који подижу Скадар, па то није никакав доказ за то, а камоли најбољи доказ. Област којом влада херцег Стјепан и раније је била војводство илити херцеі̄овина, али она је Хериеїовина тек од херцега Стјепана Вукчића Косаче, који се према дубровачкогј рукопиној грађи титулише као „Стјепан, божјом милошћу херцег од Светог Саве и господар Хумској и Поморју и велики војевода русага босанскога, кнез дрински“ (Пуцић, 1862: 116). Пјесму „Женидба краља Взкашина“ Вук је записао од Стојана Ломовића из Херцеговине, а каже да је имао још пет варијанти исте пјесме, међу којима и једну записану од свога оца Стефана Караџића (Караџић 1908: 553). 
следник ранијих јунака, противника дукљанских краљева, као што би и краљ Вукашин био контамициони лик. Он је у тим песмама заменио раније владаре, пре свега дукљанске краљеве из Скадра. Овде се не можемо упуштати у претпоставке зашто је до те замене дошло. Можемо само скренути пажњу на то да се негативна оцена Вукашина и Мрњавчевића у народној традицији поклапа с оценом дукљанских краљева, посебно Бодина и његових наследника, у Лейойuсу йой Дукљанина (1995: 212-213).

Исти аутор напомиње да помоћу „улоге Скадра као епског центра не треба ипак изводити закључак да је дукљанска епоха наше историје остала у живом сећању народне песме. За такав закључак нема никакве основе. Реч је о нечем другом. Може се претпоставити да је постојала епска традиција о старој Дукљи која се касније угасила и да је епски Скадар заостали мотив из те традиције који је нашао место у каснијим песмама“ (1995: 213).

Скадар на Бојани у десетерачкој усменој поезији зидају Мрњавчевићи, а не Балшићи чија је првобитна престоница овај град. Да и не говоримо о томе да у усменој књижевности Скадар не зидају они који су га стварно зидали. Само од себе се поставља питање зашто у десетерачкој усменој предаји о зидању Скадра овај град не подижу Балшићи. До одговора на ово питање долазимо увидом у структурализацију српске усмене епике - преко Јелене Балшић, жене зетског кнеза Ђурађа II Страцимировића Балшића а кћерке кнеза Лазара, која је у усменој традицији љуба-удовица Милоша Обилића и родоначелница зетске, па црногорске династије Црнојевић. Кретање браће Балшића између католичанства и православља (иако се Страцимир Балшић упокојио у манастиру Дечани као монах Сава) и неучествовање Ђурађа Страцимировића Балшића у Косовском боју, само су неки од узрока одсуства интересовања усмене епске поезије за зетске господаре Балшиће. ${ }^{3}$

3 О односу усмене књижевности према Балшићима подробније говоримо у сегменту 4.2.1. необјављене докторске дисертације на тему Јелена Балшић у среgњовјековној, усменој и савременој књижевносиии, одбрањене 23. новембра 2019. године на Филолошком факултету Универзитета у Београду. 
Мирјана Детелић наводи: „У једној албанској варијанти градитељ Скадра је епски јунак Роса, а у зидине се узиђује његова сестра Фа (епонимни јунаци средњовековног имена за град - Росафа)“ (2007: 388). Албанско усмено предање о зидању града Росафа записао је писац Скендербегове биографије Марин Барлети (Marino Barlezio), фратар из Скадра у другој половини петнаестог вијека. Град Росафу у овом предању подиже Роса, а жртва духу-покровитељу грађевине је његова сестра Фа. Предање је топоним Росафа разложило на Роса и Фа зато што у албанском језиу фа значи дјевојка. У варијанти албанске пјесме о зидању тврђаве Росафа - о којој Стефановић говори уз помоћ Хисаинта Хекара (Iscaint Ekar), француског конзула у Скадру (1933: 263-264) - старац даје предлог да мајстори узидају жену, како би се обдржала сјеверна кула тврђаве на скадарском бријегу која се дању зида а ноћу руши. Росина сестра Фа, која има дијете у колијевци, без одупирања је прихватила да буде узидана - и то кад је, иронијом судбине, непозвана дошла да види како напредује градња. У албанској усменој поезији са мотивом узиђивања жене у тврђаву Росафа нема историјских личности, али назив Росафа није аисторичан. Росафа је други назив за Скадар: долази из култа светих Срђа и Вакха којима је посвећен храм на десној обали Бојане, по свој прилици подигнут на темељима рановизантијског храма. На град Скадар је пренијет назив сиријског града Росафа у коме је, почетком четвртог вијека, погубљен Свети Срђ. Сам од себе пада у воду Стефановићев исказ: „Име Рошафа није могуће идентификовати, нити оно има какву историјску основу“ (1933: 312), односно његова тврдња да је у албанској пјесми „псевдо-историјска локализација у имену Рошафа“ (1933: 290). ${ }^{4}$

\section{Скадар и Мрњавчевићи}

Да би се разумјело дејство историје из позадине усменог епског наратива о „Зидању Скадра“ потребно је извести на чистац позицију Вукашина Мрњавчевића у односу на кнежевину Зету. Архивска руко-

4 Нијесу само Арбанаси у средњем вијеку Скадар називали Росафом а Скадарско језеро Росафатским. Монах Никон Јерусалимац каже својој духовној кћери Јелени Балшић: „Видјесмо да у земљи Диоклитијској тамо, на језеру Росафатском, острва су многа [...]“ (Горички зборник, лист $85 \mathrm{r})$. 
писна грађа показује да Зету није заобишло његово друштвено дјеловање као савладара цара Уроша. Поред тога, Вукашин Мрњавчевић је у Зети имао два зета. Двије његове кћерке, Оливера и Милица, удате су за зетске кнежеве Ђурађа I Балшића и Страцимира Балшића, синове родоначелника зетске династије Балшић. ${ }^{5}$ Раде Михаљчић сматра да се утицај краља Вукашина више ширио преко родбинских веза него „заокружењем области којом је управљао“ (Михаљчић, 1994: 586).

Браћа Балшићи који су након смрти свога оца Балше заједно владали Зетом, након безуспјешног напада Ђурађа I Балшића на Котор 1367. године, склопили су „савез са српским краљем Вукашином“ (Jovović, 2009: 219) који „се марта 1350. године помиње у прилепском крају са титулом жупана“ (1994: 586). Вукашин Мрњавчевић је крунисан 1365. године. ${ }^{6}$ „У то вријеме била је на врхунцу моћ Балшића. За свега једну и по деценију они су се од мале властеле преобразили у велике обласне господаре“ (Ћирковић 1970: 33). Ђурађ I Балшић био је најистакнутији међу браћом, иако није најстарији: „Послије пада Николе Алтомановића он је поред кнеза Лазара био најјачи и најугледнији српски великаш““ (1970: 31). Сима Ћирковић истиче да

5 „Једну другу кћер краља Вукашина, по имену Рушна, отац удаде за Матеја, сина Јована Кантакузина, цариградског цара““ (Орбин 1968: 51) - каже Мавро Орбин, и додаје да је краљ Вукашин Кантакузину у мираз дао „сва подручја која је поседовао у Албанији“ (Орбин 1968: 51). Међутим, Сима Ћирковић у својим „Коментарима 'Краљевства Словена' Мавра Орбина“ негира ову Орбинову тврдњу: „Преко ње је Орбин отишао врло далеко и уплео у излагање једну побркану причу о унутрашњим ратовима у Византији. Уједно је повезана породица Ђурђа Бранковића с краљем Вукашином. Подаци су нетачни и ослањају се на коментар Леунклавија“ (Ћирковић 1968: 313).

6 „Као што је за време царевања Душановог Урош био краљ, тако је сада Урошу као цару уз бок стајао са краљевском титулом Вукашин који није припадао светородној породици Немањића“ (1970: 23). У историографској литератури је већ истакнуто да се Вукашин Мрњавчевић није могао самозвано прогласити краљем како то казује усмена традиција - зато што према византијском државном поретку ту титулу није могао додијелити нико осим цара. Византија је престала да додјељује титуле тек након смрти цара Уроша. Од српских обласних господара, титулу краља имали су само Вукашин Мрњавчевић и Твртко I Котроманић. Михаило Ласкарис напомиње да у грчким изворима петнаестог вијека „није редак случај да се с р п с к

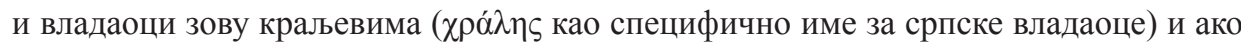
нису краљеви““ (Ласкарис, 1997: 81'1). 
ИСТОРИЈСКА ПОЗАДИНА УСМЕНОГ ЕПСКОГ НАРАТИВА О ЗИДАҢУ ...

је Балшићима „постављење Вукашина за краља и савладара сасвим одговарало, јер су на тај начин добили моћног заштитника у царевој непосредној близини““ (1970: 22).

Да се закључити да је краљ Вукашин Балшићима помагао као што је цару Урошу одмагао. Цар Урош је 1368. године Ђурађа I Балшића назвао својим одметником, што „значи да му више ни формално није био послушан ни лојалан“ (1970: 27). Краљ Вукашин је могао бити од помоћи своме зету и савезнику Ђурађу I Балшићу и у његовом одметању од цара Уроша. Поред стицања моћи преко родбинских веза, Балшићи су искористили друштвене околности након смрти цара Душана. Пелумб Џуфи (Pelumb Džufi) наглашава: „Постављење владавине Балшића у Зети остварило се као чин подјеле и непријатељства са насљедницима Стефана Душана 1368. године“ (Džufi, 2012: 234), док Милан Шуфјал појашњава: „То су скоројевићи из круга малих ратника, који гдјекад у једној јединој особи згушћују процес генерација. На читавом подручју бившег српског царства ничу овакви типови. Најбољи примјер за то је краљ Вукашин и његов брат Угљеша“ (1991: 103).

Вукашин Мрњавчевић је у Зети заступао цара Уроша и прије него што је постао краљ. Дубровчани се у службеној комуникацији са званичном Зетом обраћају Вукашину Мрњавчевићу и Јелени, остарјелој удовици цара Душана која је након смрти свога мужа управљала Улцињем и појединим зетским трговима. Односе у троуглу цар Урош, краљ Вукашин и Балшићи као обласни господари средњовјековне Зете могуће је истраживати и поред оскудице примарних историјских извора - „односи Балшића према српском царству и појединим обласним господарима једва се дају назрети“ (1970: 27). Према Сими Ћирковићу, сагледавање веза између Балшића и српског царства могуће је од 1362. године, што ће рећи од иницијативе Дубровчана за организовање мировних преговора са Котором: „Они су крајем априла писали цару Урошу, царици и великашима који могу бити од користи, а три недјеље касније су упутили и посланика старој царици и Вукашину, тада утицајном великашу“ (1970: 15). Дубровчани почетком 1364. године шаљу посланика Вукашину Мрњавчевићу и Балшићима ради ослобађања путева трговцима. У вези са тим Ћирковић саопштава: „Он тада није имао власт над цијелом српском државом као што је 
имао доцније, од 1365, када га је цар Урош узео себи за савладара и додијелио му краљевску титулу. Он је у ово доба морао бити савезник Балшића и због тога је био интересантан за Дубровчане. Можда блискост Ђурђа Балшића и Вукашина потиче отуда што је Ђурађ Балшић за жену имао Оливеру, кћер Вукашинову“ (1970: 19). Приликом напада Ђурађа I Балшића на Котор овај град није могао очекивати помоћ од цара Уроша, „откако му је савладар постао савезник Балшића Вукашин“" (1970: 23).

Цар Урош је 22. августа 1357. године у Оногошту (данас Никшић) издао повељу о миру између Дубровника и Котора, која налаже и рјешавање проблема без ратовања, уз обавезу царевог посредовања. Балшићи се у ову активност нијесу укључивани и зато што се наведене сукобљене стране налазе мимо области којом су они управљали. Но, околности су се у српском царству убрзо измијениле:

Цар Урош се од средине 1369. па све до послије Маричке битке скоро уопште не појављује у изворима. Мавро Орбин у већ споменутом дјелу [Краљевстиво Словена] каже да је Урош од 1369. био сасвим у рукама Вукашиновим, због тога што се раније био повезао са Николом Алтомановићем и кнезом Лазаром против краља [Вукашина]. Коалиција је, по подацима којима је располагао Орбин, била поражена, а Урош је од тада сасвим онемогућен. То казивање, свакако, није ни измишљено ни исконструисано, али се не може контролисати савременим изворима. Ипак треба подвући да није у нескладу са збивањима која само фрагментарно познајемо (1970: 27).

У повељи издатој 4. априла 1370. године краљ Вукашин Дубровчанима каже да ће „сваке законе и хрисовуље пређе бивше господе испунивши извршавати и не потварати, но чак више и крепче потврђивати са сваком усрдношћу и жаром срдачним, не само у земљи Краљевства ми, но још и околним поморским градовима потврђивати законе и хрисовуље пређе краљевства ми бивших краљева и царева“ (Маринковић 1996: 148). Примјећујемо, заједно са Симом Ћирковићем, да краљ Вукашин у овој повељи не помиње цара Уроша коме је савладар, „што је у нормалним условима незамисливо“ (1970: 27). 
На позив Ђурађа I Балшића, краљ Вукашин и његов син Марко долазе у Скадар средином јуна 1371. године, ради заједничког сучељавања са Николом Алтомановићем, који је претходно напао Дубровник и запријетио нападом на Зету:

Већ почетком јуна 1371. краљ је из Скопља кренуо ка Призрену, а средином мјесеца је са сином Марком стигао у Скадар и ту се састао са Ђурђем Балшићем. Отуда је требало да заједно пођу на Николу Алтомановића према Оногошту. Савезници су затражили од Дубровчана да превезу један дио Ђурђеве војске. Дубровчани су се показали врло спремни да изврше овај задатак, па су обећали да ће Ђурђеву војску превести на Николину земљу, да ће чувати прелаз и вратити војску кад буде потребно. Тражили су само да се Ђурађ уздржи од напада на Котор том приликом, да се Которани не би могли жалити угарском краљу. 'Други пут речени Ђура може да наступи против Которана кад му се свиди - поручивали су Дубровчани преко свог посланика““ (1970: 29). ${ }^{7}$

Од напада на Алтомановића се одустало због доласка Турака на Марицу, гдје је краљ Вукашин отишао у помоћ свом брату деспоту Угљеши. ${ }^{8}$ Пошавши од Константина Јиричека, Лидија Делић са-

7 Балшићи су више пута нападали Котор, али никад нијесу успјели да га освоје. Раде Михаљчић наводи да „иако је био српски краљ, Вукашин није испољавао интересовање за судбину града Котора. Град Котор је препустио својим рођацима Балшићима, тим пре што је између Котора и властеоске породице Војиновића, односно Алтомановића, постојала трајна сарадња“ (1994: 594).

8 Драгољуб Шћекић каже да стихови „биће боја с Вукашином краљем / и његовим манитијем Марком“ из епске пјесме из Васојевића „О Николи Олтомановићу, (Порука Оса Отманова)“ - у чијој је историјској позадини Никола Алтомановић - „упућују на Вукашина и Марка који су намјеравали напасти од Скадра к Оногошту, Зети и Приморју“ (Шћекић, 1998: 479). Као што је познато, краљ Вукашин и син му Марко били су спремни да са Ђурађем I Балшићем крену из Зете према Оногошту у борбу са Николом Алтомановићем - из Зете, а не према Зети (Скадар је тада био престоница Зете). У поменутој десетерачкој пјесми из Васојевића није назначено гдје се краљ Вукашин и његов син Марко налазе док Осо Отмановић писмом позива васојевићког војводу Рајича да му помогне у планираном нападу на Лаза Припчевића, Вука Бранковића и Мусу са Звечана, што војвода Рајич одбија. 
општава: „Алтомановићева област, с једне, и место из кога су краљ Вукашин и Ђ. Балшић намеравали да нападну, с друге стране, односно потенцијални правац кретања Вукашинове војске необично се поклапа с топографијом песме Женидба краља Вукашина, односно с географским тачкама Скадар - Дурмитор. Но, то је, по свему судећи, само коинциденција која није изнедрила ни активирала супротстављање Скадра Пирлитору““ (Делић, 2006: 204 ${ }^{125}$ ).

Пошавши од претпоставке Л. Марковића да су Мрњавчевићи „из једног мјеста између Сиња и Имотског у Херцеговини“ (1993: 293), Светислав Стефановић је сагласан са мишљењем Јована Томића да Вукова пјесма о зидању Скадра није настала далеко од Скадра, што „може бити Горња Арбанија, Црна Гора и југозападни део Херцеговине, где је јака традиција 'Мрњавчевића"“ (1933: 264). Саопштивши да није познато кад се тачно у српском усменом пјесништву десила контаминација интернационалног мотива узиђивања жене приликом подизања грађевине, Стефановић каже:

Из Барлетија и Хекара имамо несумњив доказ да је у XV веку постојала легенда о узиданој жени везана за Скадар. Ова географска локализација је довољно важна, јер доказује егзистенцију такве легенде у околини Скадра из тог доба. Вукова песма такође је везана за Скадар, а сем тога добијена [je] од певача, старца Рашка, из Колашина, дакле из крајева суседних Скадру (1933: 292).

И пјесма Тодора Икова Пипера из необјављених рукописа Вука Стеф. Караџића, насловљена „Зидање Скадра““ (Вук, II_p, 15) записана је у скендеријском крају - у пиперском мјесту Сретња, које се налази десетак километара сјеверно од Подгорице, што ће рећи око сто километара сјеверозападно од Скадра. Сматрајући да у позадини Новака ковача у Подруговићевим пјесмама „Марко Краљевић познаје очину сабљу“ (Вук, II, 57) и „Марко Краљевић и Муса кесеџија“ (Вук, II, 67) стоји средњовјековни ковач Новак из Котора, Новак Килибарда каже: „Епске личности Новака ковача нема нигдје у нашој епици, сем у пјесмама које су из постојбине Подруговића, Старца Милије и Рашка, из крајева у којима су се рађале легенде о Мрњавчевићима, и с којим су историјски Мрњавчевићи имали живих веза и додира. У пјесми из 
Македоније Вукашинову сабљу ковао је Јањо из Солуна, а једну је Марко купио у Цариграду““ (Килибарда, sine anno: 81). ${ }^{9}$

Познато је да се родоначелником Мрњавчевића сматра Мрња кога је цар Душан довео на свој двор. У предању о Мрњавчевићима које је Јован Мишковић записао у Шумадији (која је дијелом насељена становништвом из црногорске Херцеговине) стоји да је цар Душан својој сестри Грубани омогућио да сама изабере мужа и да је она изабрала Мрњу (Карановић, 1937: 53). Милан Карановић, који је пописао породична предања о поријеклу од Мрњавчевића (Карановић, 1937: 42 и даље) наводи и податак Јована Ердељановића да у Кучима има триста тридесет домова Мрњавчића. Колективно памћење Куча каже да су Старокучи поријеклом од Мрњавчевића а Новокучи од Скендербега. Васа Чубриловић, позвавши се на Марка Миљанова, саопштава: „По овој традицији, унук Гојка Мрњавчића, Грча Ненадин, населио се најпре поред реке Цијевне и од његових потомака су стари Кучи“ (Чубриловић, 1983: 314). А Милан Карановић напомиње: „Љуба Ковачевић мисли да су ти Мрњавчићи од Гојка Балшића, праунука краља Вукашина“ (1937: 53). Мавро Орбин наводи Гојка и Иваниша као синове Ђурађа Страцимировића Балшића (Орбин 1968: 72), али примарни историографки извори не потврђују њихово постојање (Ћирковић, 1968: 323). ${ }^{10}$

Колико је познато, међу насљедницима Страцимира Балшића и његове жене Милице једини праунук краља Вукашина је Балша III Ђурађевић Балшић, чији се једини син (коме име није сачувано) упокојио док је био дијете. Милица, жена Страцимира Балшића родила је Ђурађа II Страцимировића Балшића који је, због опасности која му је пријетила од Турака, зетски престо из Скадра премјестио у Улцињ.

9 Ристо Ковијанић и Иво Стјепчевић, позвавши се на Владимира Ћоровића и Јована Томића, наводе которски докуменат из 1396. године у коме се помиње Novacus spatarius Cathar (Ковијанић, Стјепчевић 1957: 148).

10 Не треба прећутати да Медо Пуцић каже: „Бияше се у ово доба Ђурађ Страшимировићъ Балшићъ помирио с кральем босанскием, али како се є краљ страшио да му Ђурађ не остане увъри, запроси Републику да би задръжала у ямство єдног од Ђурђевих синова, кои се находиаху у Дубровнику, али Вњће неусхтьде нипощото учинити, него одмах пошль у Оцинь Андриу Минчетића да допрати к оцу младе кнежеве“ (Пуцић, 1858: IV). У вези са наведеним, преостаје провјера вјеродостојности Пуцићевог преписа дубровачког документа, како би се на основу тога утврдило да ли је потребно додатно истраживање. 
Ђурађ І Балшић и Оливера, кћерка краља Вукашина нијесу имали мушко потомство. Пошавши од Божићевог рада „Зета и Мрњавчевићи“ (Божић 1976), Сима Ћирковић саопштава: „Иза Оливере остала је кћерка Јелисанта, која је имала унуку Јелену, удату за Рајка Монету, властелина Балше III. После смрти господара Рајко је ступио у млетачку службу. За нашу тему је од значаја чињеница да је он 1443. тражио да буде прокуратор српске цркве на Скадарском језеру. Рајко је умро између 1433. и 1439. и оставио је за собом жену Јелену и синове Николу, Јакова и Момчила“ (Ћирковић, 2000: 50). ${ }^{11}$

Иван Божић наведи три кћерке Ђурађа I Балшића _ Јелисанту, затим кћерку непознатог имена и Јевдокију (1970: 51). Прве двије кћерке Ђурађа I родила је његова прва жена Оливера, а трећу његова друга жена Теодора. Он у родослову Балшића наводи и два сина Ђурађа I Балшића, од којих ниједан није унук краља Вукашина Мрњавчевића. То су његов син Константин из брака са Теодором и његов незаконити син именом Ђурађ, који је живио у Венецији. Према претпоставци Милана Шуфлаја (Milan Šufflay), син Константина Балшића и његове жене Јелене је Стефан де Марамонте (Stefan de Maramonte) (1991: 104). Он је, колико је познато, без насљеђа _ као што је то и Ђурађ, ванбрачни син Ђурађа I Балшића.

У Божићевом родословном стаблу Балшића нема података о удаји Ђурађеве и Оливерине кћерке Јелисанте, пемда Божић у свом касније објављеном раду „Зета и Мрњавчевићи““ (Божић 1976) говори о њој као мајци Јелене, жене Рајка Монете. За кћерку непознатог имена из брака

11 Јелену, жену херцега Стјепана Косаче Мавро Орбин погрешно наводи као праунуку Вукашина Мрњавчевића по мушкој линији, односно као унуку његовог сина Андрије а кћерку његовог унука Недељка Момчила (1968: 273). Јелена, кћерка Балше III а жена Херцега Стјепана је чукунунука Вукашина Мрњавчевића, и то женском линијом. Она је праунука његове кћерке Милице, која је родила Ђурађа II Страцимировића Балшића - оца Балше III Балшића. Кћерке Балше III су Јелена, која је удата за херцега Стјепана Вукчића Косачу и Тедора, која је удата за кнеза босанске области Доњи Краји Петра Војсалића. У свом роману Није било ирољећа Перивоја Поповића за Јелену Балшић, кћерку кнеза Лазара удату за зетског кнеза Ђурађа Срацимировића Балшића, а потом за хумског војводу Сандаља Хранића Косачу, каже се да је „унука краља Вукашина, нећакиња Краљевића Марка. Мрњавчевића свијетло рођење“ (Поповић, 2010: 68). То је са историјског становишта материјална грешка, а неподударање са историјом ни литерарним разлозима није оправдано. 
Ђурађа I Балшића и његове жене Оливере Божићев родослов Балшића каже да је умрла послије 1443. године. Јевдокија, трећа кћерка Ђурађа I Балшића жена је јањинског деспота Есауа ден Буонделмонти Аћајуолија. Према наведеном родослову, Јелисанта и њена сестра непознатог имена немају дјеце, а Јевдокија има сина Ђорђа и сина непознатог имена. Божић на истом мјесту не наводи кћерку Ђурађа I Балшића именом Гоисава (Гојсава), која је удата за хумског властелина Радича Санковича а о којој свједоче архивска грађа Дубровника (1858: IV) и епитаф на њеној надгробној плочи код Коњица (Павић 1986: 85). ${ }^{12}$

Остаје недоумица у вези са тим како је Дабижив Монета у сродству са Мрњавчевићима и Балшићима. Говорећи о његовом тестаменту и биљешци о извршењу тестамента (Дубровник, 6. XII 1449; 2. I 1450. године), Сима Ћирковић појашњава:

У Дубровнику је пре 1449. саставио тестамент Дабижив Монета или Монетиић, како у документу наводи [...] / Državni arhiv Dubrovnika, Distributiones testamentarum 14 fol. 104/. По свему судећи, Дабижив је припадао некој грани породице Монета која је у своје претке убрајала Ђурађа I Балшића и краља Вукашина, чијом је ћерком Ђурађ био ожењен (2000: 50).

12 Сима Ћирковић наводи да је жена Ђурађа I Балшића Оливера у скадарском крају, подигла цркву „својим новцем пошто је довела мајсторе из земље свога оца и обдарила је од свог мираза с мужевљевом дозволом“ (1968: 313). Након што упућује на радове Љубића, Валентинија, Јиричека, Марковића и самог Ћирковића, Војислав Ђурић каже: „Много касније, 1444. год. Оливерини потомци, тврде Млечићима да је она цркву подигла per magistros conductos de regno patris sui и да ју је богато обдарила“ (Ђурић, 1970: 416). Исти аутор даље казује: „Податак о доласку градитеља из Повардарја у Зету, саопштен послије готово седамдесет и пет година, може бити истинит у односу на Оливерину задужбину, али може, исто тако, да буде посљедица шире појаве мајстора с југа у држави Балшића, која се дуго памтила“ (1970: 416). Исти аутор додаје: „Храму је данас изгубљен траг“ (1970: 416). У каснијем, заједничком раду Гордане Бабић_Ђорђевић и Војислава Ј. Ђурића стоји да је Оливера Балшић подигла цркву Свете Марије „у селу Лоренцу“ (Бабић Ђорђевић, Ђурић, 1994: 161). Неколико сачуваних средњовјековних цркава у Зети оквирно се смјештају у четрнаести и петнаести вијек. Прецизно се „посредством извора може датовати једино црква Св. Николе у селу Склава (данас Скла или Цкла), на обали Скадарског језера, јер ју је Балша III даровао Јелисанти, кћери Ђурађа I Балшића“ (1994: 164) и Оливере, кћерке краља Вукашина. 
Ћирковић притом наглашава да овај Монета није повезан са синовима Рајка Монете, као и то да би (према датуму писања његовог тестамента) он „пре припадао генерацији Рајка Монете него његових синова“" (2000: 50).

Према Ивану Божићу, постоји могућност да је у родбинској повезаности са Мрњавчевићима и Константин Балшић, син Ђурађа I Балшића и његове друге жене Теодоре. Позвавши се на радове четворице аутора (М. Šufflaya, Д. Атанасијевића, Г. Острогорског и G. Schiró), Божић саопштава: „Преко своје полусестре Јелисанте, удате према доцнијим прилично непоузданим подацима за једног члана куће Црнојевића, и Константин би био у сродству с краљем Марком“ (1970: 56). Константин Балшић је у свом властољубљу инспирисан и родбинским везама, а посебно тиме што му је ујак источномакедонски обласни господар Константин Дејановић Драгашевић (који стоји иза епског бега Костадина, побратима Марка Краљевића), чија је кћерка Јелена жена византијског цара Манојла II Палеолога. Свијест о томе исказује Филип Барели, бивши управник финансија Ђурађа II Балшића у Шуфлајевом историјском роману Косйаgин Балиић, објављеном под псеудонимом Алба Лими (Alba Limi):

„Кћи овога Константина, дакле нећакиња Теодорина Јелена, удала се прије пар година за византијског цара Манојла Палаиолога. Према томе је царица византијска прва сестрична Костадина и његова полубрата Мркше Жарковића. Већ из овог кратког родословља можете разабрати“, настави Барели, „каковом помњом разапињу Балшићи чудновату мрежу крви, да дигну моћ своје обитељи“ (Šufflay 1920: 17).

Балшићи су дебело користили своје женидбено_удадбене везе. Одмах након смрти краља Вукашина раскинут је брак између Ђурађа I и Оливере, кћерке краља Вукашина. Након тога се Ђурађ I оженио Теодором, удовицом зетског великаша Жарка Мркшића и завладао облашћу којом је он управљао. И поред свих породичних веза и сарадње са Мрњавчевићима, Ђурађ I Балшић је након Маричке битке присвојио призренску област синова Вукашина Мрњавчевића, као и град Костур. Да и не говоримо о браку Балше II Балшића и Комнине, кћерке Јована Асена - „деспота бератског“ (Јиричек 1952: 315) - који није имао синова, и који је као брат царице Јелене господарио прос- 
тором који му је на управу дао цар Душан. Руђина, кћерка Балше II и Комнине Балшић (која није имала браће) удата је за зетског великаша Мркшу Жарковића, сина Жарка Мркшића. Овдје остављамо по страни природу бракова Балше Ђурађевића Балшића са Маријом и Бољом, кћеркама арбанашких великаша Никите Топије и Које Закарије. Његов отац Ђурађ II Стацимировић Балшић је атипачни Балшић - и на личном, и на породичном, и на друштвеном плану

\section{Према пјесмама}

Скадар на Бојани подигнут је у петом вијеку прије Христа, а у усменој епици овај град подижу браћа Мрњавчевића. Према Јовану Ковачевићу, писма папе Лава I и папе Гргура I архиепископима скадарским указују на то да глани град античке провинције Превалис није Дукља него Скадар. Ковачевић сматра да у прилог томе иде и црквена организација која се ,увијек подударала са државно-административном организацијом Царства“ (Ковачевић, 1967: 243). ${ }^{13}$ Слушалац/читалац Рашкове пјесме „Зидање Скадра“ не мора знати ко је и кад подигао Скадар на Бојани да би био свјестан њеног значења. Њена семантичка суштина није у документарности - у њој није главно ко подиже град него колико се човјек, кад је на кољенима, може уздати чак и у оне са којима живи.

У пјесми „Зидање Скадра““ Тодора Икова Пипера „грађу граде девет Мрњавчићах“. Наспрам вилиног императивног захтјева из пје-

13 Милан Шуфлај саопштава:

Средовјечни ‘славниј град Скьдьр' (талиј. S k u t r i постало је од локатива Скьдьри), сијело дукљанских кнезова и српских младих краљева, не покрива се посвема с римском вароши. Цитадела остала је наравски иста, али утврђена варош помакла се око цитаделе нешто на запад. Варош имала је и отворених предграђа. У 14. вијеку 'под Скадром на Дримцу с многим дивним полатама' спомиње се двор српских краљева. Био је разорен г. 1331. у борби за пријестоље, али је затим опет обновљен. Преузимају га Балшићи. Посве пропада у вријеме пролазне окупације Скадра под Турцима (1392-1395). Мјесто на којем је тај двор стајао назива се г. 1416. 'la corte de lo imperator' (Šufflay, 1991: 10).

Поменута борба за престо односи се на синове краља Стефана Дечанског, Душана и његовог полубрата Симеона. Битку је изгубио Симеон Немањић. 
сме Старца Рашка да се у темеље града узида жена једног од браће Мрњавчевића, и то она која донесе мајсторима ручак, у Пиперовој пјесми тај императив долази преко сна Гојка Мрњавчића (,тада ће се отемељит грађа“"). У објема пјесмама само је Гојко одржао сопствену ријеч. Пиперова пјесма је амалгам митологичности и историчности, али је ближа је историји од Рашкове пјесме на исту тему. Након што је до груди зазидана, Гојковица у Пиперовој пјесми тражи да нахрани свог једногодишњег сина Сава, а након дојења га разбија о темеље града и проклиње:

\section{„Градите га, девет Мрњавчића, Градите га, злосретње ви било, Брзо ви [га] преузели Турци“.}

Слиједи финална епска формула: „Што су рекли, тако је [и] било“. Ово је још један примјер „пророковања уназад“ _ да употријебимо синтагму Јакоба Буркхарта (Jacob Burckhardt) која ce, како наводи Јосип Бабић (Babić, 1982), односи на испуњење клетве краља Вукашина и благослова цара Уроша из Рашкове пјесме „Урош и Мрљавчевићи“ у епској биографији Марка Краљевића. ${ }^{14}$ У „Зидању Скадра“" Тодора Икова Пипрера спајени су мотиви жртве-невјесте и жртве-дјетета духу-покровитељу грађевине. Жртвована невјеста проклиње градитеље, међу којима је и њен муж, и у грчкој усменој пјесми „Зидање моста на Арарату“. Од пет варијанти албанске пјесме

14 Након пада Скадра под Турке, године 1474, зетски господар Иван Црнојевић збјег Зећана изводи на Ријеку (данас Ријеку Црнојевића, која се назива и Обод), а потом на Цетиње. Црногорски краљ Никола I Петровић током Балканског рата узалудно покушава да добије Скадар. Историјска је чињеница да је престолонасљеднику Данилу Петровићу Есад-паша, главни командант Скадра кључеве овога града предао 25. априла 1913. године, међутим свјетске силе Скадар су уступиле Албанији. Божо Ђурановић, говорећи о томе, наводи стихове Радована Бећировића:

„Граде Скадре, тврда качанице,

Црногорска грдна касапнице,

Најгласити на крајини граде,

Црногорски узалудни наде““ (Ђурановић 2013: 30).

У пјесми Будимира Дубака „Пад Скадра“ краљ Никола и његов узалудни покушај да добије град на ријеци Бојани асоцирани су епским краљем Вукашином и зидањем Скадра (Дубак, 2008: 36) . 
са мотивом узиђивања жене које наводи Новак Килибарда, „само у једној варијанти говори се да је дијете доношено на грађевину док му је мајка-жртва била у животу“ (1982: 13²). Мајка-жртва у варијанти пјесме о зидању тврђаве Росафа о којој говори Хекар моли мајсторе да током зидања оставе отвор за колијевку.

„Тешањ зиђу до три неимара“ - стих је пјесме из Краусове збирке, записане у Осови код Жепча, у којој су имена неимара Раде, Петар и Гојко. На основу чињенице да је у њој само Гојко испоштовао завјет ћутања, као и карактеристичних имена Раде неимар и Гојко, уз напомену да је у граду Бару постојао неимар именом Раде, Стефановић сматра да је пјесма о зидању Тешња несумњиво „везана за Вукову варијанту“ (1933: 281). „Врло је за ова разматрања илустративно како у босанској варијанти из Жепча не три брата Мрњавчевића, него три брата неимара, међу њима Раде, граде мост, а жртвује се жена најмлађег брата Гојка. Раде неимар је ту у улози краља Вукашина“ (1933: 301). Стефановић закључује:

Будући историјског извора и карактера, традиција Мрњавчевића морала се најпре развијати непосредно у вези са самим исторјским личностима, апсорбујући постепено и стране јој, легендарне и митске мотиве, као и већ готове легенде, које су пре тог морале бити везане за друге историјске или псевдо-историјске личности, или и за безимена лица, или општа имена каква налазимо у митским и легендарним темама. На тај начин је првобитна историја Мрњавчевића, у њеној изворној локацији могла апсорбовати и легенду о Зидању Скадра, и дати јој псеудо-историјски карактер (1933: 294).

Са друге стране, Бошко Сувајџић цитира Илариона Руварца: „И ја сам летос слушао слепца једног, где пева песму о зидању Скадра у којој се браћа несу звали Мрњавчевићима, на које је дакле она тек касније пренесена“" (Сувајџић, 2011: 66). ${ }^{15}$

\footnotetext{
15 Новак Килибарда истиче да Мрњавчевићи као позната породица и Скадар као древни град Рашковој пјесми „Зидање Скадра“ дају додатну важност у односу на пјесме у којима су безимени градитељи и безначајне грађевине, односно да је албанску усмену пјесму „Пала магла на Бојану“ (Мекули, 1975: 149) - која је скромног умјетничког досега - од заборава могло сачувати једино увјерење „да се рад и обичај морају поштовати“ (1982: 22).
} 
Вукашин и Угљеша Мрњавчевић из Рашкове пјесме о зидању Скадра брата Гојка добијају на матрици структурирања бајке, односно преко њене иницијалне формуле „била три брата“. Отуда је, у контексту двојице старијих, у хоризонту читалачког очекивања предвидиво понашање најмлађег брата. Понашање браће Мрњавчевића је истом логиком градирано и у пјесми „Урош и Мрљавчевићи“, у којој се чак ни Гојко по добру не познаје. „А ти, стриче, војевода Гојко, / мало ти је војводства твојега“" - кори свога стрица краљев син Марко, који знаде на коме је царство. ${ }^{16}$ Основа грешности старије браће у Рашковој пјесми „Зидање Скадра“ толико је „разрађена да се у њено ткиво комотно смјестио књижевно оформљен лик омраженог краља Вукашина, једног од великаша који 'на комате раздробише царство'. Тако је семантика интернационалног мотива о невјерној браћи и правичности најмлађега брата остала неповријеђена, иако је прерасла у простор који је испунила национално-историјска тематика““(1982: 22). ${ }^{17}$

16 Три брата Мрњавчевића су и у усменим пјесмама „Урош и Мрљавчевићи“ (Вук, II, 34), „Пропаст царства српскога“ (Вук, II, 46) и „Млогостручна невјера“ (Милутиновић, 15), које не говоре о њиховом неимарству. У поменутој пјесми из Пјеваније ирноїорске и херцеіовачке нијесу назначена имена два брата Вукашина краља. А то што владика Василије Петровић у својој „Историји о Црној Гори“ као брата краља Вукашина наводи Гојка, а не Угљешу може се разумјети као знак ретроактивног дјеловања усмене традиције (Василије, 1996: 42). У грчкој усменој пјесми о зидању моста на ријеци Арарату узидане су три сестре на различитим локацијама. У једној од варијанти ове пјесме једна од три сестре узидана је у мост на Арарату, док су друге двије узидане на Дунаву и у Валони (у другој варијанти исте пјесме оне су узидане на Дунаву и у Београду). Дало би се говорити и о три сестре као интернационалном мотиву усмене традиције. Он се налази и у бокешкој легенди „Тре сореле“. „Зоја Карановић је прва приметила да се у уводу песме 'Зидање Скадра' префињеном симболиком сугерише обредни драмски конфликт. Помињање броја три у усменој култури увек поседује интенцију да означи суму света. Један је целина, два амбиваленција, три је мноштво свеукупност космоса“ (2011: 65) - саопштава Бошко Сувајџић, и додаје: „У уводу песме 'Зидање Скадра' акцентује се број три, као митско-магијски принцип на коме почива уређеност света. Три брата се помињу три пута у уводном дистиху. Три пута се понавља синтагма 'град градила'. Град се гради три године дана, у зидању грађевине учествује триста мајстора“ (2011: 65).

17 Примијетивши де се стих „краљ Вукашин вјеру погазио“ из Рашкове пјесме „Зидање Скадра“ налази и у библиографској одредници „Погазити“ у Српском рјечнику Вука Стеф. Караџића, Јован Делић казује: „Вукашин је невјера и по томе наговјештава Вука Бранковића“ (Делић, 1990: 244_245). Мало је усмених пјесама у 
ИСТОРИЈСКА ПОЗАДИНА УСМЕНОГ ЕПСКОГ НАРАТИВА О ЗИДАЮУ ...

Нада Милошевић-Ђорђевић констатује да је устаљено мишљење да је мотив узиђивања жене ручконоше накнадно укључен у епско пјевање о зидању Скадра (Милошевић-Ђорђевић, 1971: 342). Позвавши се на Мирчу Елијаде (Mircea Eliade), Миодраг Павловић о невјести-жртви говори као о ритуалној прељуби, односно као о антижртви (Павловић, 1993: 142). У појединим културама нијесу жртвоване ни животиње које дају млијеко (1993: 143), камоли жене. Бошко Сувајџић наводи да Гордана Ђерић даје до знања да се тврдња Жерара да удата жена не може бити жртвована не може „применити у нашем жанровском систему, јер је демантују примери од младе Гојковице до гравидних жена које су примораване од стране власти да се купају у хладној води како би, наводно, пала киша““ (2011: 64). Потребан је опрез у вези са узимањем младе Гојковице као примјера те врсте, зато што је она књижевни лик који је у корелацији и са усменим пјесмама мимо српске усмене епике.

Стефановић истиче да, за разлику од других пјесама о узиђивању људске жртве, у којима од градитеља жртву тражи водени дух, птица из облака, па и вила, или је предлажу сами градитељи, само у српској епској пјесми вила и омета градњу и захтијева узиђивање жртве. На основу тога што се у грчкој варијанти албанске пјесме о зидању Скадра помињу три брата из Црне Горе и вила предлаже да у грађевину буде узидана жена, исти аутор изводи закључак да је то утицај српске усмене поезије (1933: 311). ${ }^{18}$ Банашевић са правом примјећује да „ни господин Арнаудов ни господин Стефановић не воде довољно рачуна о арбанашким версијама легенде, - које морају има-

којима краљ Вукашин није у знаку негативне карактеризације. У Вуковим збиркама то су „Пропаст царства српскога“ (Вук, II, 46) и „Удаја шћере краља Вукашина“ (Вук, V, 677). Тиме што говоре о краљу Вукашину као жртви, њима се условно казано придружују све три варијанте пјесме „Марко Краљевић познаје очину сабљу“ (Вук, II, 57, 58; Вук, II_p, 38). У усменим предањима о родоначелништву он је од негативне карактеризације заштићен природом жанра.

18 Из двадесет пет збирки, зборника и часописа, Бранислав Крстић наводи шездесетак усмених пјесама балканских Словена са мотивом виле која омета градњу (Krstić, 1984: 603). Да жена буде зазидана како би се одржала градња у једној варијанти албанске пјесме „савјет не даје старац него свейаи. Нама се чини да је ова појединост или ствар новијег датума, или је пак синтагма свече живи метафоричка одредница за мудрост и старост“ (1982: 13²). 
ти важности и због њиховог најстаријег помена - први јер је чврсто убеђен у грчки извор мотива и његову бугарску посредничку улогу у њеном ширењу, а други јер верује у словенски, односно српски дух ове поетизоване легенде“ (1928: 376). Он притом подсјећа на то да се мотив жртвоване жене која се осмјехује градитељима, док мисли да се на градилишту шале кад јој саопштавају да ће бити узидана, не налази само у српској пјесми о зидању Скадра него и у једној бугарској пјесми и њеној румунској варијанти (објема из зборника Михаила Арнаудова). А у вези са млијеком младе Гојковице, „зарад здравља и зарад лијека“, изгледа му - насупрот Стефановићу - „вероватније да тој течности, ако је уопште ње и било увек није придавана никаква важност све док се легенда о Скадру није формирала и раширила по народу““ (1928: 375). ${ }^{19}$

Занимљива је напомена Вука Караџића уз 1219. стих Милијине пјесме „Женидба Максима Црнојевића“ (Вук, II, 89): „По ӥјесмама се говори, да су данашње Бушатлије од Иванбеговића; али они сами доказују да су од Мрњавчевића, који су Скадар зидали“. Као да и ово друго није по пјесмама. Ново Вуковић луцидно описује настанак накнадне традиције у дурмиторском крају под утицајем Ломовићеве пјесме „Женидба краља Вукашина“, чија „основа није дурмиторска“ (2001: 24). Већ на основу тога се може закључити да би овај аутор лако ријешио загонетку појаве Мрњавчевића у усменом наративу о зидању Скадра да је боље упознао историју средњовјековне Зете. „У епској слици

19 У Рашковој пјесми „Зидање Скадра“ наратор рачуна на то да је слушаоцима познато вјеровање о љековитости млијека са скадарске тврђаве. Како примјећује Бошко Сувајџић, „на свом крају, у мотиву млека које помаже нероткињама да се опашу породом, а у светлу Вукових коментара уз текст, песма поприма одлике културно-историјског предања“ (Сувајџић, 2011: 67). У Љубишиним Причањағима Вука Дојчевића свијест о предању изражава се напоредо са усменом пјесмом о зидању Скадра (Љубиша, 1949: 161). Петар М. Божовић, након теренског истраживања, свједочи вјеровање да је бијела течност која прокапава из скадарског зида љековита сеже до Кроје. Један од примјера тога вјеровања је жена из Враке код Скадра која, према Божовићу, тврди да јој се повратило млијеко за дојење дјетета након што је пила бијелу течност са скадарске тврђаве (Божовић, 1926: 274). Млијеко младе Гојковице је литерарни знак више дјела савремене књижевности, међу којима је и приповијетка „Зидање Скадра“ Маргерит Јурсенар (Marguerite Yourcenar) (Jursenar, 1980: 8). 
Скадра слиле су се народне представе о давнашњој и новој историји““ (Путилов, 1993: 56) - како то каже Борис Николајевич Путилов.

У литератури је довољно истицано да је однос усмене епике према историји аристотеловски појаснио Вук Караџић: „, [...] пјесма није историја. У историји се гледа истина, а у пјесми се гледа како је измишљено и намјешћено“ (Караџић 1908: 553). Поезији није важно потврђивање историјских факата зато што историја опслужује поезију, а не поезија историју. Усмена епика полази од стварности, само што њена веза са стварношћу није увијек очигледна. За разлику од Рашкове пјесме „Зидање Скадра“, није тешко препознати историјску позадину такође Рашкове пјесме „Урош и Мрљавчевићи“. ${ }^{20}$ Наведене Рашкове пјесме имају различита тежишта, али обје кроз локално говоре о универзалном. У „Зидању Скадра“ „није вила која руши Град споља узрочник обредне драме. Противуречности извиру изнутра, из пољуљаног породичног склада““ (2011: 66). А у пјесми „Урош и Мрљавчевићи“ господа се „хоће да поморе, / злаћаними да пободу ножи“".

20 Безобзирност браће Мрњавчевића у пјесми „Урош и Мрљавчевићи“ исказана је и описом немоћи царевића Уроша, који о царском насљеђу не бесједи ,jер не смије од три братијенца, / братијенца, три Мрљавчевића“. Катица Дармановић саопштава:

И у распореду ликова у песми „Урош и Мрљавчевићи“ видимо знамења народног певача који на три нивоа заплиће и расплиће драму царског наслеђа, а акценат није на Урошевим родитељима (макар да се мајка Јелена помене, царица која је владала Серском облашћу после Душанове смрти и са сином била у веома добрим, скоро савладарским односима), него читав призор показује драму породице која је званично имала младог краља да понуди за престо. Дакле, Мрњавчевићи су у фокусу пажње народног певача - то је прилично верна слика историјског стања царевине у којој обласни господари полако преузимају власт и територију од Нејаког Уроша: песма, на свој начин, казује исто што и историја (Дармановић, 2016: 21).

А Владан Недић каже да се Старац Рашко више но икоји други пјевач „у грчевима наслеђеног сећања 'хватао за последњи сјај нације' - како би то рекао Леополд Ранке - али се историјске пристрасности спасавао мудрошћу коју је показао надносећи се над безумну игру око престола, око власти. [...] На Његошеве стихове о пропасти средњовековних држава наших и о великашима 'проклете душе' пао је помало и одблесак песама Старца Рашка“ (Недић, 1990: 121-122). 
Несумњиво је да усмено пјесништво о Мрњавчевићима као градитељима Скадра у позадини има и њихове везе са средњовјековном Зетом. Њихово мјесто у усменим предањима скендеријског краја у функцији је спознаје да „ништа у историји културе не умире и не нестаје без трага“" (Лихачов, 1972: 7) -како би то казао Дмитриј С. Лихачов (Дмитирий С. Лихачов). „Од крвавог Скадра царевога / иде облак преко Малесије“ (Милутиновић, 61), стихови су једне од пјесама о Боју у Мартинићима из збирке Пјеванија ирноїорска и хериеїовач$\kappa a$. Активности краља Вукашина у Зети као савладара цара Уроша, родбинске везе између Мрњавчевића и Балшића и незаинетересованост усмене књижевности за Балшиће - изузев Јелене Балшић, која се потписује као „дашти светопочившаго господина кнеза Лазара“ (1996: 207) - чињенице су које воде према одговору на питање зашто у десетерачким усменим пјесмама Мрњавчевићи зидају Скадар на Бојани. 


\section{ЛИТЕРАТУРА}

Babić, J. (1982), “Lik Kraljevića Marka u njemačkoj književnosti”, Beograd: Uporedna istraživanja, urednik N. Stipčević, Institut za književnost i umetnost, IV/2, 127-178

Бабић-Ђорђевић Г., Ђурић В. Ј. (1994), „Полет уметности“, Исйорија срйскої нароga, књига друга, уређивачки одбор С. Гавриловић и други, Београд: Српска књижевна задруга, 144-191

Банашевић, Н. (1928), „Др Свет. Стефановић, 'Легенда о зидању Скадра““, Цетиње: Зайиси, год. II, св. III, бр. 6, 373-376

Божић, И. (1970), „Доба Балшића“, Истиорија Црне Горе, књига друга, том други, уређивачки одбор Д. Вујовић и други, Титоград: Историјски институт Црне Горе, Титоград, 49-133

Божић, И. (1976), „Зета и Мрњавчевићи“, Београд: Прилози КЈИФ, 42, 20-30

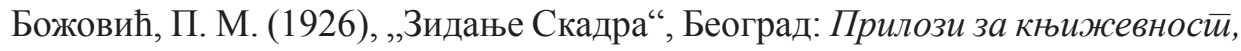
језик, историју и фолклор, VI, 2, 274-276

Вуковић, Н. (2001), „Антитетички принцип структурирања у народној пјесми Женидба краља Вукашина““, Девешиа соба, Београд: Филип Вишњић, 21-31

Дармановић, К. (2016), Тийолоїија и функиија женских ликова у ейским иеесмама Вукове збирке, (необјављена докторска дисертација), Нови Сад: Филозофски факултет

Делић, J. (1990), Траяииија и Вук Сӣеф. Караиић, Београд: БИГЗ

Делић, Л. (2006), Живоие ейске иесме, (,,Женияба краља Вукашина“ у круїу варијанай $а)$, Београд: Завод за уџбенике

Деретић, Ј. (1995), Заїонейка Марка Краљевића, (Прироgа иситоричносиии у срииској народној йоезији), Београд: Српска књижевна задруга

Detelić, M (2007), "SKADAR, Skader, Škadarac", Epski gradovi, (Leksikon), Beograd: Srpska akademija nauka i umetnosti: Balkanološki institut, Posebna izdanja, 84, 385-388

Ђурић, В. (1970): „Умјетност“, Истиорија Црне Горе, књига друга, том други, уређивачки одбор Д. Вујовић и други, Титоград: Историјски институт Црне Горе, 411-531

Јиричек, К. (1952), Истиорија Срба 1, (Политиччка истиорија), превео Јован Радонић, Београд: Научна књига

Јиричек, К. (1959), „Српски цар Урош, краљ Вукашин и Дубровчани“, Зборник Констианииина Јиричека, уредник М. Динић, Београд: Српска Академија наука, књ. I, 339-386 
Jovović, V. (2009), "Balšići između katoličanstva i pravoslavlja", Hrvatskocrnogorski dodiri / Crnogorsko hrvatski dodiri: identitet Crnogorskog primorja, Zbornik radova sa skupa održanog 6. oktobra 2007, urednik L. Čralić, Zagreb: Hrvatski institut za povijest, Matica hrvatska, 215-223

Карановић М. (1937): Динарска йлемена Немањићской иоријекла, Бањалука: Ауторско издање [Штампарија 3. Јовић и Комп.], 1_62; доступно на: https://www.zapadnisrbi.com/images/PDF/Milan-Karanovic-Dinarskaplemena-Nemanjickog-porijekla.pdf; [15. октобар 2019. године]

Килибарда, Н. (sine anno), „Пјесничка индивидуалност Тешана Подруговића“, Поезија и истиорија у нарояној књижевносиии, Београд: Слово љубве, 67-84

Килибарда, Н. (1982), „Интернационално и национално у народној књижевности“, О усменој књижевносиии, Подгорица: Побједа, 13-26

Ковачевић, J. (1967), „Црна Гора у доба римског царства“, Истиорија Црне Горе, књига прва, Уређивачки одбор Д. Вујовић и други, Титоград: Историјски институт Црне Горе, 143-277

Ковијанић, Р., Стјепчевић, И. (1957), Кулииурни живой сйароїа Койора (XIV-XVII вијек), Цетиње: Историјски институт НР Црне Горе

Костић, Д. (1935): „Преноси народних песама с једнога јунака на другога“, Београд: Срйски књижевни ілласник, нова серија, XLV, бр. 6, 452-457

Krstić, B. (1984), Indeks motiva narodnih pesama balkanskih Slovena, Beograd: Srpska akademija nauka i umetnosti, Posebna izdanja, knjiga DLV, Odeljenje jezika i književnosti, knjiga 36

Ласкарис, М. (1997), Визаниииске иринщезе у среgњовековној Србији, (Прилої истиорији визанишиско-срйских оgноса оg краја XII gо среgине XV века), Фототипско издање, Подгорица: Унирекс

Лихачов, Д. С. (1972), Поеииика сииаре руске књижевносиии, превео Д. Богдановић, Београд: Српска књижевна задруга

Милошевић-Ђорђевић, Н. (1971), Зајеgничка иеммайско-сижејна основа

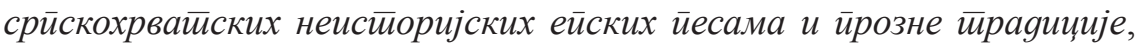
Београд: Филолошки факултет

Михаљчић, Р. (1994), „Маричка битка“, Истиорија срӣско̄ нароgа, књига прва, уређивачки одбор С. Гавриловић и други, Београд: Српска књижевна задруга, 593-602

Недић, В. (1990), „Старац Рашко, певач Вука Караџића“, Вукови иеевачи, Београд: Рад, 114-122

Орбин, М. (1968), Краљевстиво Словена, превео 3. Шундрица, Београд: Српска књижевна задруга 
Павловић, М. (1993), „Зидање Скадра на Бојани“, Оїлеgи о нароgној и стйрој срйској йоезији, Београд: Српска књижевна задруга, 139-147

Путилов, Б. Н. (1983): Јуначки ей Црноїораиа, превео Д. Аранитовић, Титоград: Побједа

Пуцић, М. (1858), [Ненасловљени предговор], Сйоменици сръбски оg 1395. gо 1423. йо ести иисма иисана оg Реиублике Дубровачке Кральевима, Десйойима, Войвоgама и Кнезовима Србъскием, Босанскием и Приморскием. Књ. I, преписао с Дубровачке архиве кнез Медо Пуцић, Београд: Кньигопечатня Княжества српског, III-XXIII

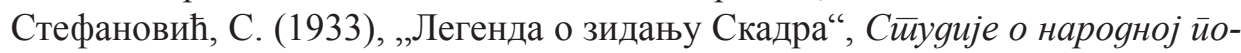
езијu; Сабрана дела Светислава Стефановића, III и IV књига, Београд: Штампарија 3. Маџаревића, 245-315

Сувајџић, Б. (2011), „Гојковичин смех: поетика жанра у усменој књижевности“, Београд: Кюижевности и језик, година LVIII, бр. 1-2, 61-75

Ћирковић, С. (1968), „Коментари и извори Мавра Орбина“, Мавро Орбин, Краљевстиво Словена, Београд: Српска књижевна задруга, 291-377

Ћирковић, С. (1970), „Доба Балшића“, Исиорија Црне Горе, књига друга, том други, уређивачки одбор Д. Вујовић и други, Титоград: Историјски институт Црне Горе, 3-48

Ћирковић, С. (2000), „Archiepiscopus Craynensis“, Подгорица: Исйоријски заиичси, год. LXXIII, бр. 1-2, 47-54

Чубриловић, В. (1963), „Постанак племена Кучи“, Београд: Зборник Филозофскої факулиеиети $а$, VII, 1, 313-333

Džufi, P. (2012), “Albansko-crnogorska podudaranja u srednjem vijeku”, preveo L. Đokaj, Balšići, Zbornik radova sa skupa Balšići, Ivanova Korita, 21-22. septembar 2011, urednik Č. Drašković, Cetinje-Podgorica: Matica crnogorska, 211-242

Шћекић, Д. (1998), „Важније биљешке и објашњења“, Ейске нарояне йјесме из Васојевића, приредио Д. Шћекић, Андријевица-Београд, Ступови, Хипнос, $473 \_526$

Šufflay, M. (1991), Srbi i Arbanasi, (Njihova simbioza u srednjem vijeku), Zagreb: Mala Azurova povjesnica

\section{ИЗВОРИ}

Андрић, И. (1996), На Дрини ћуприја; Сабрана дела, Иво Андрић, Књига прва, приредили П. Џаџић, М. Первић, Београд: Просвета

Василије, В. (1996), „Историја о Црној Гори“, Исйорија и књижевности, превео и приредио Б. Шекуларац; Књижевност Црне Горе од XII до 
XIX вијека, књига 12, уређивачки одбор Н. Вуковић и други, Цетиње: Обод, 33-56

Горички зборник [1441/42]: Манускрипт са скадарског острва Горица, саставио Никон Јерусалимац на предлог Јелене Балшић, Архив САНУ, Стара збирка, број 446. Електронско факсимил издање: http:// stari.mitropolija.me/duhovnost/gorički/default-1.html, приредио Зоран Стефановић; [8. децембар 2012. године]

Дубак, Б. (2008), „Пад Скадра“, Скаgарске елеїије, Цетиње: Светигора, 34-37

Ђурановић, Б. (2013), „Поводом 100 година од Балканских ратова: Скадру у походе“, Никшић: Голија, год. 13, бр. 18, 30-31

Jursenar (Yourcenar), M. (1980), “Zidanje Skadra”, Osmeh Kraljevića Marka, preveo Đ. Dimitrijevič, Beograd: Beogradski grafičko-izdavački zavod, 7-19

Караџић, В. С. (1908): Вукова йрейиска, књ. II, Београд: Државна штампарија Краљевине Србије

Караџић В. С. (1935), Срйске нарояне ӥјесаме, књига V, скупио их Вук Стеф. Караџић, Друго државно издање, Београд: Државна штампарија

Караџић, В. С. (1969), Срйски рјечник (1852), Београд: Нолит

Караџић, В. С. (1974), Срйске наровне ӥјесме II, (Из необјављених рукойиса Вука Сиееф. Караиића), приредили Ж. Младеновић и В. Недић, Београд: Српска академија наука и уметности

Караџић, В. С. (1988), Срйске наровне ӥјесме II, скупио их и на свијет издао Вук Стеф. Караџић, Сабрана дела Вука Караџића, књига пета, приредила Р. Пешић, уређивачки одбор Г. Добрашиновић и други, Београд: Просвета

Љубиша С. М. (1949): „Причања Вука Дојчевића“, Прийовијестии и йричања, приредио В. Латковић, Београд: Југословенска књига, 135-230

Маринковић, Р. (1996), Писах и йойииссах, (Ауйобиоїрафске изјаве среgњеї века), приредила Р. Маринковић, Београд: Нолит

Мекули, Е. (1975), „Пала магла на Бојану“, превео Е. Мекули, Београд: Мостиови, бр. 22, 149

Милутиновић, С. С. (1990), Пјеванија ирноїорска и хериеїовачка, сакупио и објавио Сима Милутиновић Сарајлија, приредио Д. Аранитовић, Никшић: Универзитетска ријеч

Николић, В. (2000), С краја на крај заборава, приредио М. Бошковић, Подгорица: ЦИД 


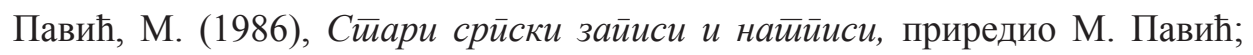
Стара српска књижевност у 24 књиге, књига деветнаеста, уређивачки одбор Д. Богдановић и други, Београд: Просвета, Српска књижевна задруга

Поповић, П. (2010), Није било йрољећа, Бијело Поље: Пегаз

Пуцић, М (1862), Сйоменици сръбски оg 1395. gо 1423. йо ести иичсма ииссана оg Рейублике Дубровачке Кральевима, Десиоииима, Войвоgама и Кнезовима Србъскием, Босанскием и Приморскием. Књ. II, преписао с Дубровачке архиве кнез Медо Пуцић, Београд: Кньигопечатня Княжества српског

Шћекић, Д. (1998), Ейске наровне ӥјесме из Васојевића, приредио Д. Шћекић, Андријевица-Београд: Ступови, Хипнос

Šufflay M. (1920), Kostadin Balšić (1392-1402), (Historijski roman u tri dijela), Zagreb: Tiskara, D. D.

\section{Rosanda V. Bajović}

\section{THE HISTORICAL BACKGROUND OF “THE WALLING OF SKADAR (SCUTARI)" ORAL EPIC NARRATIVE}

\section{Summary}

This paper aims to elucidate the links between the Mrnjavčević dynasty and "Skadar on (the river) Bojana" in decasyllabic oral poetry. In the context of the nature of oral literature, this research follows the historical facts concerning Mrnjavčevićs as relatives and associates of Balšić ruling dynasty of Zeta especially the historical role of king Vukašin in Zeta - proving thus that role of Mrnjavčevićs in the "walling of Skadar (Scutari)" epic narrative is in no way accidental.

Key words: Mrnjavčević family, Balšić family, Skadar (Scutari) on Bojana, oral epic poetry, history. 